\title{
A CATEgoria JURIDICA DOS ATOS EXISTENCIAIS
}

Transformação da Concepção Clássica de Negócio Jurídico

Trabalho apresentado em conclusão ao "Curso de Aperfeiçoamento" ministrado pelo Departamento de Direito Privado e Processo Civil da Faculdade de Direito da UFRGS durante o ano letivo de 1973, visando a habilitação para o concurso para professor assistente daquele departamento. $O$ trabatho foi aprovado em arguição oral, pelos professores Drs. Clóvis do Couto e Silva, Leonidas Caminha e Arno Schilling.

\section{Verena Nygaard Becker}

I - Introdução: a doutrina das relações contratuais fácticas

II - O conceito de negócio jurídico e o tráfico em massa 1 - O princípio da autonomia da vontade

2 - A vontade como elemento essencial do suporte fáctico de negócio jurídico:

a) o ato existencial como negócio jurídico

b) $\mathrm{o}$ ato existencial como ato-fato

III - Conclusão

1 - "O futuro do direito privado" (Raiser)

2 - O princípio da proteção à confiança

IV - Jurisprudência

\section{I - INTRODUCÃO A DOUTRINA DAS RELAÇóES} CONTRATUAIS FACTICAS

Sob a denominação geral de "atos existenciais" (*) compreende-se uma grande variedade de atos que diferem entre

(*) Denominação introduzida no nosso vocabulário pelo prof. Clóvis do Couto e Silva, na tentativa de traduzir a expressão alemã daseinsvorsorge. 
si, mas que tem em comum a característica de todos visarem atender às necessidades básicas do indivíduo, tais como vestuário, alimentação, transporte, água, energia elétrica, etc. Tendo como finalidade satisfazer necessidades vitais da existência humana, são atos cuja prática se impõe a todos os indivíduos. Trata-se naturalmente de um conceito essencialmente variável no tempo e no espaço, pois o que se considera necessidade vital varia de uma sociedade a outra, de uma época para outra, dependendo do tipo de cultura e do grau de evolução de um povo.

Praticados assim quotidianamente por todos os indivíduos, formam uma parcela siginficativa do chamado "tráfico em massa" que vem crescendo de importância devido, principalmente, ao aumento das populações, ao avanço tecnológico dos nossos dias e a conseqüente elevação do nível de vida. O tráfico em massa caracteriza-se pela tipificação e standartização das relações jurídicas que o constituem. Esta tipificação é muitas vezes legal: outras vezes, resulta simplesmente da prática constante e idêntica dos mesmos atos por todos ou pela maior parte dos indivíduos integrantes da coletividade e em conseqüência adquire uma certa cogência, integrando os usos e costumes do tráfico, que passam a regrar a conduta dos indivíduos.

F muito revelador do processus jurídico-social acima descrito, o fato de o Estado, à medida em que determinados serviços de caráter existencial vão sendo considerados imprescindíveis à coletividade, decidir convertê-los em monopólio estatal ou reservar para si a exclusividade de sua prestação, seja diretamente pelo próprio Estado, seja mediante concessão de serviço "público": aquele serviço de caráter existencial "privado", cujo tráfico generalizado e cujo espontâneo reconhecimento de cogência pelos indivíduos, induziu - Estado a declará-lo público.

A pergunta que aqui surge é a de se saber se as relações jurídicas do tráfico em massa que tem como finalidade uma prestação existencial podem ser qualificadas de negócio jurídico e mais precisamente como contrato, pois que se trata sempre de negócios jurídicos bilaterais.

Este problema foi examinado e largamente discutido na Alemanha desde 1941, quando foi suscitado pelo Prof. HAUPT no seu trabalho intitulado "Das Relações Contratuais Fácticas" (Ưber Faktische Vertragscerhältnisse) (1) Observe-se desde logo que a expressão não é feliz, pois contém contradiç̃o evidente como também observaram Pontes de Miranda (2) e Nikisch (3): se se trata de relações contratuais, elas serão forçosamente jurídicas e não fácticas e vice-versa. $\mathrm{Na}$ verdade, o que ela quer significar, são certas situacões, semelhantes às contratuais, que no entender tas situaçoes, semelnar de manifestacões de vontade, ou manifestações de vontade válidas.

Com a doutrina das relações contratuais fácticas, HAUPT defendeu a tese de que a teoria clássica do negócio jurídico não serve mais em nossos dias, para explicar uma série de situações e a da conseqüente necessidade de construir-se uma nova teoria do negócio jurídico a fim de nela trangê-las. Esta colocação originou o que alguns chamaram de "crise do negócio jurídico" e as opiniões se dividiram, tanto na doutrina como na jurisprudência. No Brasil, o problema não foi suscitado, nem por uma, nem por outra; como tem implicações profundas, repercutindo nas concepcões que estão à base de todo ordenamento jurídico, cremos interessante abordá-lo, ainda que parcial e suscintamente.

As situações visadas por HAUPT sob a denominação geral de relações contratuais fácticas dividem-se em quatro grupos e são as seguintes (4):

1 o "contato social" no qual se reconhecem situações semelhantes às relacões contratuais;

2 - relações jurídicas de prestação que se estabeleceram sem declaração de vontade, tendo sido satisfeitas por uma das partes ao menos;

3 - as situaç̃̃es oriundas de relações duradouras nascidas de contratos nulos ou ineficazes que, sem atenção à deficiência funcionam de fato e devem ser protegidas;

4 _ as situacóes criadas pelo moderno tráfico em massa, se contratos são celebrados sem participação da vontade individual (contratos de massa e de adesão).

As discussões no entanto mostraram que os dois primeiros grupos devem ser retirados do âmbito das relações conros contato social suscita tão só problemas de responsabilidade extra-contratual, constituindo campo à parte e que é o da teoria da culpa in contrahenho, ou seja, obrigações que surgem no trato negocial e que não tem seu fundamento ou sua fonte num contrato, porque este ainda não foi celebrado ou o foi, e é nulo. O que HAUPT denominou de relações jurídicas de prestação que se estabeleceriam sem declaração de vontade não oferece o menor problema, já que a lei permite que as declarações de vontade para a conclusão de contrato sejam tácitas ( $\$ 151$ do BGB, Arts. 1079 e 1984 do C. Civil) e não se compreende mesmo que tais situações tenham sido problematizadas. 
Assim, a doutrina das relações contratuais fácticas abrange, no estado atual da discussão, tão somente as situações criadas por relacões jurídicas duradouras oriundas de contratos nulos (especialmente de trabalho e de sociedade) que não podem, decretada a nulidade, ser apagadas do mundo jurídico, seja porque uma das prestações não pode ser devolvida (o trabalho efetivamente prestado), seja porque há interesses importantes de outra ordem a serem resguardados (interesses de credores da sociedade de fato); e as situacóes criadas pelo tráfico em massa no campo das prestaç̃es existenciais. O presente trabalho se propõe examinar tão somente esta última categoria.

\section{II - O CONCEITO DE NEGÓCIO JURIDICO E O \\ TRAFICO EM MASSA}

Com a doutrina das relações contratuais fácticas levantou HAUPT o problema da necessidade de se revisar desde a sua base a teoria do negócio jurídico, porque, tal como é tradicionalmente entendido, não se adapta às exigências do moderno tráfico em massa, especialmente no que diz respeito às relacões jurídicas que tem por objeto uma prestação de caráter existencial. Exemplos de relações desta espécie são as que se estabelecem entre o usuário e a empresa concessionária do transporte público, entre o particular e a companhia fornecedora de água, gás, eletricidade, etc. Constituem tais relações os chamados contratos de massa ou de adesão, os quais, se contratos são, representam efetivamente uma transformação da concepcão clássica de contrato e que é a adotada pelos códigos modernos. A fim de se examinar esta questão, impõe-se o exame preliminar do conceito de contrato ou, mais amplamente, de negócio jurídico.

A teoria do negócio jurídico, elaborada no século passado, numa época em que o indivíduo era considerado como valor supremo, representou uma das formas, e talvez a mais importante, pelas quais o ordenado jurídico reconheceu a liberdade individual, através da consagracão do princípio da autonomia da vontade. O negócio jurídico foi inicialmente concebido como o instrumento por meio do qual a vontade individual podia produzir efeitos jurídicos, criando direitos e obrigações; constituiu-se em pedra angular de toda ordem jurídica privada. As duas teorias, a da vontade e a da declaração, explicitaram de forma diversa o mesmo fenômeno: a consagração jurídica do dogma da autonomia da vontade a qual era, em última análise, vontade arbitrária. Só mais tarde é que se reconheceu que a vontade não pode ser fonte de direitos e obrigações, pois os efeitos jurídicos decorrem exclusivamente da lei. A vontade foi reduzida então a elemento do suporte fáctico de fato jurídico: este é que, após a incidência da norma jurídica, produz efeitos jurídicos. Este reconhecimento contribuiu decisivamente para o abandono do voluntarismo no direito.

No entanto, como segundo as palavras do Professor Armando Câmara, «cultura é relação», este fenômeno não pode ser compreendido isoladamente e é interessante tecer algumas consideracões meta-jurídicas.

A teoria do negócio jurídico foi profundamente influenciada pelo espírito individualista, fruto do liberalismo político dominante na época em que foi elaborada e que em verdade só se modificou com as duas grandes guerras. O liberalismo estabelecia uma separação nítida e quase antitética entre o Estado e a sociedade, menosprezando aquele como um poder exterior ao grupo social, sempre pronto a oprimi-lo, valorizando a sociedade como o lugar onde o indivíduo, valor supremo e livre por natureza, se afirma e se realiza. Tarefa principal do Estado liberal é a de proteger a liberdade individual; suas intervencões na esfera particular se limitam a medidas de polícia com a finalidade de regulamentar o exercício das liberdades que pressupõe, não colocando em questão a liberdade de comércio e indústria, a propriedade particular e o dogma da autonomia de vontade. «O direito individual sobre o qual repousa o edifício liberal, presume-se satisfeito quando o individuo goza de uma esfera de autonomia que lhe garante o exercício do mesmo. Tem seu fundamento no homem, seja porque é inerente à natureza humana, seja porque não depende senão do próprio homem realizá-lo. O direito individual delimita negativamente a competência do Estado; legitima o dever de abstencão do Poder e a faculdade de re.sistência do indivíduo. O direito social, ao contrário corresponde à consagração jurídica da necessidade. Seu fundamento repousa numa obrigação positiva do Estado em relação aos indivíduos. (...) Às liberdades clássicas, que são formais e abstratas, pois que é freqüentemente impossível ao homem fazer uso delas em razão de sua dependência econômica, se oporiam as liberdades concretas, caracterizadas pelo uso efetivo que proporcionam ao direito. Com o direito individual, sou livre de ir e vir; a esta liberdade teórica, o direito social acrescenta um cupon de transporte» (5).

$O$ conceito de liberdade individual e de autonomia da vontade sofreu no correr dos tempos, modificacões profundas. A liberdade do homem, após ter sido por ele descoberta, foi pri- 
meiramente abstratamente garantida e protegida (Declaracões de Direitos Individuais) mas foi necessário depois, realizá-la in concreto. «Enquanto a liberdade, entendida como prerrogativa inerente à natureza humana se acomoda com seu reconhecimento abstrato, a liberdade compreendida como uma maneira de ser da existência humana exige a transformação do meio social. À liberdade metafísica é suficiente ser afir mada; à liberdade real, é necessário proporcionar a possibilidade de se exercer» (6). Assim, além de se reconhecer aos homens a faculdade de proverem livremente à realização de sua personalidade e de regularem seus interesses segundo critérios pessoais, torna-se necessário fornecer a cada um as prestações que sua situação requer para que encontre o bem estar e a segurança inseparáveis de uma existência verdadeiramente humana. Ao direito de fazer algo, que de nada vale se o indivíduo não tem os meios, se acrescenta o direito de obter algo. «Assim o direito de trabalhar se torna o direito ao trabalho, isto é, o direito de obter um emprego; o direito de se instruir, o direito ao ensino, ... (7). No plano político passou-se então da democracia liberal para a democracia social. Foi no entanto somente com as duas grandes guerras que estas transformações se completaram, modificando radicalmente a concepção do papel a ser desempenhado pelo Estado na vida do indivíduo e da sociedade. «Desde o início do século, a administração pública passa, sempre em maior grau, de simples garantia da ordem, a sujeito de prestações de caráter existencial» (8).

\section{1 - O Princípio da Autonomia da Vontade}

A evolução foi assim no sentido da crescente intervenção do Estado no domínio outrora deixado ao indivíduo. Esta intervenção na esfera particular se faz em benefício do interesse geral, para proporcionar a todos os indivíduos o gozo efetivo de uma liberdade concreta. É dentro dessa perspectiva que se há de entender a afirmação corrente de que se observa hoje uma restricão sempre maior ao princípio da autonomia da vontade. «Se o ser humano não tivesse diante de si campo em que poderia exercer a sua vontade, não se poderia falar de personalidade» (9). A conquista da liberdade humana foi definitiva. O princípio da autonomia da vontade (também chamado de autonomia privada ou auto-determinação) é o princípio jurídico através do qual a ordem jurídica sanciona a liberdade individual que no plano político pode ser reconhecida de forma mais ou menos ampla conforme as concepções dominantes numa determinada sociedade, num dado mo- mento. Todavia, hoje não se entende mais por autonomia da vontade, como os pandectistas alemães do século passado, o poder ilimitado e quase arbitrário da vontade na criacão dos efeitos jurídicos. Depois que se reconheceu que a eficácia jurídica decorre da lei e não da vontade, não tem mais sentido falar-se de autonoima fora do âmbito de incidência da lei, de modo que «a alusão à autonomia é alusão ao que se pode querer dentro desses limites» (10). Do ponto de vista jurídico, a vontade sempre teve limites; as regras sobre existência, validade (cuja sanção é a nulidade) e eficácia dos atos jurídicos em geral, nada mais são senão a expressão dos limites traçados pela lei à vontade. Esta, após ter sido identificada com o próprio negócio jurídico, passou a elemento essencial do seu suporte fáctico, ao lado da lei. Assim, o negócio jurídico pode ser conceituado como o instrumento que a ordem jurídica coloca à disposição dos indivíduos para que, através de manifestações de vontade, regulem seus interesses, adquirindo, modificando ou extinguindo direitos e obrigações, livremente, dentro dos limites por ela estabelecidos. E autonomia de vontade, como o princípio jurídico segundo o qual a ordem jurídica reconhece ao indivíduo a possibilidade de compor, através de manifestações de vontade, o suporte fáctico para a incidência de regras jurídicas que prevêem para ele determinados efeitos jurídicos (11). O ordenamento jurídico sanciona assim, em se tratando de negócio jurídico bilateral, o regramento de interesses que resultou de acordo de vontade, porque pressupõe que, como resultou de vontades autônomas, que se exercem dentro dos limites em que reconhece a autonomia, corresponda àquilo que as partes quiseram, e as regras jurídicas sobre anulação de negócio jurídico o asseguram.

Tal como é entendido pelo código civil relativamente aos negócios bilaterais, o princípio da autonomia da vontade aparece em dois momentos: antes da conclusão do contrato, significando a possibilidade que tem o indivíduo de conclui-lo, se e com quem quiser; no momento da conclusão, sob a forma da liberdade no regramento do conteúdo, através da possibilidade de escolha das cláusulas contratuais, sendo então chamado «princípio do auto regramento da vontade».

A teoria das relações contratuais fácticas argumenta que o campo do tráfico em massa não oferece os pressupostos para a incidência daqueles princípios, de sorte que não se poderia ver nas relações jurídicas de prestações existenciais, contrato $(12)$.

De fato, valoriza-se neste campo precipuamente o interesse geral; o indivíduo como tal é relegado a um segundo plano. Na prestação de serviços existenciais que se dirige a to- 
dos, abstrai-se das características individuais, procedendo-se, como se expressa Pontes de Miranda (13) a «certa abstratização dos figurantes» e as necessidades individuais são padronizadas para poderem ser atendidas globalmente. Não seria eficiente o serviço que, dirigido a todos, levasse em conta as exigências de cada um. O indivíduo só é considerado enquanto participante do tráfico e não como personalidade singular.

As relações de prestação estruturam-se então segundo critérios fixos, estabelecidos no interesse geral; constituem assim relações jurídicas tipificadas, ou, como diz Pontes de Miranda, «contratos com tipicidade subjetiva» (14), ao que no entanto se deve acrescentar, «e objetiva». Assim, ainda segundo o mesmo autor, «os negócios jurídicos que resultam de atos da vida em público podem ser de tipicidade tráfica tal como ocorre com as compras e vendas em público.... (15).

Todo aquele que necessitar da prestação, há de participar da mesma relaç̃o, no sentido de que ela é idêntica para todos, estruturada que foi, de antemão, da melhor forma a atender eficientemente as exigências de todos. Por outro lado, como condição de eficiência da prestação, imprescindível se torna também, evitar ao máximo, quaisquer conflitos e atritos de ordem individual no desenvolvimento daquelas relações. Por isso, muitas das regras gerais sobre negócios jurídicos, especialmente as referentes à invalidade, não são aplicáveis, ou o são com restrições, às relações de prestação existencial.

Assim sendo, observa-se a primeira limitação ao princípio da autodeterminação através do que se chama de «coação a contratar» (Kontrahierungszwang), em outras palavras, o dever e a obrigacão que tem o Estado ou a empresa concessionária do serviço público, de prestar o serviço a todo aquele que o exigir; não lhes sendo facultado escolher entre prestar a um ou alguns e recusar a outros, em função de características individuais de pessoas ou grupos. Como observa Pontes de Miranda (16), tal dever não resulta do caráter monopolístico que pode ter a empresa, mas da natureza existencial do serviço, e as infrações a ele, através de discriminações, feriram - princípio da isonomia, uma vez que a oferta ou a invitação à oferta por parte daquele que presta serviço, se dirige a todos. A seu turno, tampouco o indivíduo tem a possibilidade de escolher entre contratar com um ou outro quando a empresa que presta o serviço, tem caráter monopolístico, o que ocorre freqüentemente (fornecimento de água, luz, telefone, ...) Nesta hipótese, a possibilidade de escolha fica reduzida à decisão entre aceitar a prestação por parte daquele que a oferece ou não aceitá-la e ficar privado do serviço.
A segunda limitação que se observa é quanto a liberdade no regramento do conteúdo do contrato e não menos significativa, porque o regramento individual das cláusulas contratuais é substituído pelo regramento legal, ocorrendo a tipificação legal do contrato quánto ao seu conteúdo. Os contratos de massa caracterizam-se por ter seu conteúdo pré-fixado, unilateralmente no interesse geral, excluindo assim a possibilidade da participação individual no seu regramento. $O$ indivíduo adere simplesmente a tal contrato, que é por isso também chamado de contrato de adesão.

O princípio da livre determinação do conteúdo do contrato que incide amplamente no direito civil, no campo do direito das obrigações, através do grande número de normas dispositivas que contém, é, em outros setores do direito, grandemente limitado. Isto ocorre sempre que há interesses gerais que prevalecem sobre interesses individuais, requerendo proteção maior. Estas hipóteses vem aumentando, na medida em que se abandonam as perspectivas liberais, dando-se maior importância à dimensão social do indivíduo, atribuindo ao Estado, maior número de tarefas a serem por ele desempenhadas em benefício da coletividade. Assim é que intervém no meio social, transformando-o, e a moderna sociedade de planificação econômica e social é exemplo desta transformação. Uma das técnicas mais empregadas pelo Estado é precisamente a da regulamentação do conteúdo negocial. «préestabelecendo o conteúdo ou parte do conteúdo do negócio jurídico bilateral» (17). O tabelamento dos preços de bens de consumo considerados de primeira necessidade e a determinação do salário-mínimo são exemplos da intervencão do Estado com a finalidade de proteger interesses gerais, limitando a liberdade individual no regramento de negócios jurídicos bilaterais.

Também na esfera estritamente particular observa-se limitaç̃es ao princípio da livre determinação do conteúdo contratual, através das condições gerais de negócio, estabelecidas por certas empresas (de transportes, de hotelaria, de seguro, etc.) com a finalidade de racionalizar e uniformizar, para simplificar, a conclusão e o desenvolvimento de contratos, porque as relações que se estabelecem entre a empresa e os clientes são numerosas e sempre iguais umas às outras. As condicões gerais de negócio estabelecem um regramento geral do conteúdo do contrato e se aplicam a todos os negócios celebrados pela empresa; cada cliente a elas se submete, ou não conclui o negócio. A validade de tal procedimento é discutida; também o é a sua natureza jurídica e há os que 
vêem nelas verdadeiras normas jurídicas a que faltaria tão somente a característica da obrigatoriedade do direito positi vo, porque o empresário que as edita, não é legitimado para a edição de direito (18). Em todo o caso, observa Larenz, «como via de regra é de se esperar a submissão do cliente a elas, as condições gerais de negócio funcionam facticamente como normas jurídicas».

E partindo dessas observações que HAUPT afirma, relativamente às relações jurídicas de prestação existencial que «um contrato cairia no vazio, porque não há mais nada a ajustar» (19). De fato, estando todo o conteúdo do contrato prédeterminado, nada mais há a ajustar, não restando ao indivíduo senão aceitá-1o, submetendo-se àquela determinação.

Face a estas limitações ao princípio da autonomia da vontade, sendo ela o próprio fundamento do negócio jurídico, justificada está a dúvida quanto a poderem ser as relações de prestação existencial qualificadas de negócio jurídico.

Todavia, o princípio da autonomia da vontade não é um princípio absoluto; ele comporta gradações, o que já se verifica no próprio código civil; amplamente consagrado no direito das obrigações, através das normas dispositivas e interpretativas, mais limitado se encontra no direito de família e no direito das coisas, através de maior número de normas cogentes e de figuras típicas que estes setores contêm, porque regulam relações humanas por sua natureza ou por seus efeitos, de importância fundamental para o Estado. «A manifestação de vontade supõe autonomia de vontade, auto-regramento, mas o que se considera autonomia não é sempre o mesmo» (20). Tendo-se conceituado, como o fizemos, a autonomia da vontade com a possibilidade que tem o indivíduo de compor, através de manifestações de vontade, o suporte fáctico para a incidência de normas jurídicas que lhe atribuem determinados efeitos, e o negócio jurídico, como o resultado dessa incidência, forçoso é reconhecer que, para que haja negócio jurídico, basta um mínimo de autonomia, pois de resto, a questão é a de saber o que a lei prevê para a sua incidência, deslocando-se assim grande parte do problema para o plano do direito positivo. (Quanto mais numerosas as suas exigências, menor será a autonomia).

Por outro lado, é preciso não perder de vista que a explicitaç̃o da autonomia de vontade como a liberdade de concluir negócios e a de regramento do seu conteúdo, é feita a partir das normas que estruturam o negócio jurídico tal como é concebido pelo código civil; e que esta concepção foi influenciada pelas idéias liberais, refletindo o espírito individualista que o informa. Além disso, os fatos que ele visava regular, no início do século, eram diversos dos atuais, tendo a realidade social, política e econômica se transformado profundamente de lá para cá. Um dos traços mais marcantes desta transformação é a progressiva massificação das relações jurídicas, na medida em que se passou da democracia liberal para a democracia social.

É preciso reconhecer que hoje, ao lado do campo próprio de aplicação do negócio jurídico, tal como é regulado pelo direito civil, visando essencialmente relações jurídicas de estrutura individual, outro campo existe, em que se estabelecem relacões jurídicas com características de massa, relações cujos pólos não são os indivíduos singularmente considerados, mas a coletividade, vale dizer, a massa. A questão está mal formulada se ela for colocada em termos de «crise» do negócio jurídico, ou de «prestabilidade» da teoria clássica na época contemporânea. A teoria do negócio jurídico conserva seu campo próprio de atuação, que é aquele constituído de relações jurídicas de estrutura individual e a grande maioria dos negócios entre particulares, principalmente os de vulto, como observa Flume, (21) são concluídos nos moldes tradicionais previstos pelo código. A revisão da teoria do negócio jurídico a que os autores se referiram como sendo uma necessidade imperiosa, de fato o é, porque é preciso saber se a concepção clássica é suficientemente elástica para abranger também as relações jurídicas do tráfico em massa, de forma a se poder estender a elas a aplicação das normas jurídicas que definem e estruturam o negócio jurídico.

Já se evidenciou que o negócio jurídico não supõe só e sempre o máximo de autonomia que consiste em poder-se contratar-se com quem e como se quiser. O mínimo de autonomia, é não constranger o indivíduo a emitir manifestação de vontade porque aí, ou ter-se-á criado dever de manifestar vontade, o que diz respeito ao plano da eficácia (este dever é o que tem a empresa concessionária de serviços públicos em relação ao Estado e resultou do contrato de concessão), ou se estará negando o próprio conceito de pessoa. Por isso é que esse mínimo é encontrável no campo das prestações existenciais em massa. A relação de prestação existencial nasce em virtude do ato de quem aceita a prestação: «não se pode negar o que há de ato autônomo no entrar no ônibus que passa...» (22).

Mas isto é exigência mínima do próprio conceito de personalidade e não basta ao negócio jurídico, o qual, como resultado da incidência de normas jurídicas sobre suporte fáctico composto por manifestação autônoma de vontade, requer 
também o mínimo de autonomia para ambas as partes, na determinação do conteúdo (composição do suporte fáctico), que não se verifica quanto aos atos existenciais. É verdade que o reconhecimento, pelo código civil, do princípio da autonomia de vontade naqueles termos amplíssimos corresponde a concepção que a democracia liberal tinha de liberdade individual. Na medida em que esta se transformou, como se mostrou, no sentido de concretizar-se, tinha de transformarse também a concepção de autonomia de vontade, porque esta não é senão a projeção jurídica daquele princípio político. $\mathrm{O}$ indivíduo goza hoje de maior liberdade porque dispõe dos meios concretos de exercê-la e esta liberdade só tende a aumentar, através da multiplicacão dos tipos de prestacões existenciais oferecidas à coletividade e a acessibilidade sempre maior e mais fácil dos bens lato sensu a maior número de pessoas. Por isso torna-se o campo do tráfico em massa cada vez mais extenso e mais importante e o do negócio jurídico individual, mais restrito, porém não se pode dizer que se torne menos importante.

Paralelamente a esta evolução, foi se operando um estreitamento da autonomia de vontade; entretanto, quanto a sua essência, ela não pode deixar de ser o que é: a liberdade maior ou menor no momento da conclusão do negócio jurídico e a liberdade, maior ou menor, na determinação do conteúdo negocial.

\section{2 - A Vontade como Elemento Essencial do Suporte \\ Fáctico de Negócio Jurídico}

O argumento central da teoria das relações contratuais fácticas para negar constituirem as relações de prestação existencial negócio jurídico, diz respeito a teoria das fontes e é o de que tais relações se estabelecem a partir do fato da utilização da prestação e não a partir de manifestações de vontade. A utilização da prestação, é, segundo ela, uma conduta objetiva sem nenhum conteúdo volitivo. Falou-se por isso, em «teoria dos dois níveis» (Zwei-Ebenen-Theorie), significando a igual relevância do suporte fáctico com vontade e do su porte fáctico com fato. Se a relação jurídica se estabelece por forca da utilização da prestação e se esta não se constitui em manifestação de vontade, sua fonte não pode ser negocial. Este é o significado da denominação «relações contratuais fácticas»: relações contratuais cuja fonte não é um contrato, mas um fato.

O exemplo utilizado por HAUPT e pelos demais autores que se detiveram na análise desta questão, é o do transporte público coletivo: a relação de transporte entre o passageiro e a empresa transportadora, nasce não por força da conclusão de um contrato entre eles, mas pelo fato de entrar o indivíduo no ônibus. Neste momento nasce a relação jurídica, da qual o pagamento da tarifa, a que o passageiro está obrigado, é efeito. Uma obrigação bilateral nasceu, não do consenso, mas de um fato.

Karl Larenz, que também defendeu este ponto de vista, denominou aquele fato de «conduta socialmente típica» ou «conduta social - típica» e a colocou, no seu Lehrbuch, entre as fontes de obrigação, dizendo: «o moderno tráfico em massa acarreta que, em alguns casos, segundo a concepção do tráfico, assume-se obrigacões, estabelecem-se relaçóes jurídicas obrigacionais, sem que verdadeiras manifestacões de vontade sejam emitidas» (23). Estes casos são os que se referem às prestações existenciais imprescindíveis que podem ser utilizadas por qualquer pessoa, nas condições da tarifa. «As declarações de vontade se substitui a oferta pública de fato de uma prestação (ao lado da publicação da tarifa) e a utilização fáctica da prestação por um participante do tráfico. Ambos, a oferta pública de fato e a utilização fáctica da prestacão, não representam declaracões de vontade dirigidas à produção de determinados defeitos jurídicos, mas uma conduta correspondente, a qual, pelo significado social típico, tem os mesmos efeitos jurídicos da atuação jurídica negocial». (23)

A oferta pública através do colocar à disposição a prestação e a aceitação através da utilização dela, não são adequadas a configurar a conclusão de contrato, como a entende a lei civil, porque não há consenso. Assim, as regras jurídicas que regulam o contrato são aplicáveis ao desenvolvimento da relação jurídica de prestação, mas não se aplicam ao surgimento dela, porque falta ao suporte fáctico, elemento essencial, a vontade concordante. Segundo esta orientação, $o$ ato existencial, ou, na terminologia de Larenz, já aceita, a conduta social típica, é então ato-fato.

O interesse da distinç̃o está em se encontrar o fundamento jurídico para justificar a não aplicação aos atos existenciais, das normas jurídicas relativas a invalidade do negócin jurídico. Este é ponto que causa alguma perplexidade, mas de fato, no campo do tráfico em massa ninguém pensará em anular um ato existencial por incapacidade relativa do agente ou sob a alegação de ter havido erro por exemplo, desde que o ato «se realize dentro de moldes normais e adequados» (24).

A convicção geral é no sentido de que o menor ou o lou- 
co possam trafegar no bonde ou no trem, fazer compras em supermercado e refeições em restaurante, obter o fornecimento de água ou energia elétrica, e assim por diante, sem se cogitar de se estavam ou não autorizados por seus representantes legais ou mesmo se os tinham, não se investigando siquer a capacidade das pessoas quando elas se comportam adequadamente. $\mathrm{O}$ ato existencial, visando atender necessidades básicas do indivíduo é por definic̃̃o atender necessidades em lugar padrão tráfio de normalidade estabelecido por usos e costumes do tráfico, muitas vezes previstos na própria lo to de determinado serviço. Os pressupostos de «validade» do ato existencial são então somente objetivos e não subjetivos: exige-se a conformidade da conduta a um padrão objetivo e não a conformidade dela aos elementos subjetivos do agente. Por isso, denominou-o Larenz de «conduta social típica».

$O$ problema cresceu de interesse na Alemanha, porque jurisprudência desse país se utilizou dessa concepção para fundamentar alguns julgados, decidindo pela existência de uma obrigação contratual nascida de conduta social típica, apesar da declaração expressa de vontade da parte em sentido contrário. (Ver item IV).

As opiniões da doutrina dividiram-se, por assim dizer, em duas correntes: a que vê no ato existencial manifestacão de vontade e a que lhe nega qualquer conteúdo volitivo.

\section{a) O ato existencial como negócio jurídico}

Esta corrente conta com o maior número de adeptos Esser, Siebert, Lehmann, Flume, Bidlinsky, alguns dos quais muito radicais nesta opinião. $O$ que todos eles pretendem, por caminhos um pouco diversos, é, em face da tese de HAUPT, «salvar» a teoria do negócio jurídico.

Para qualificar de negócio jurídico os atos existenciais, partem da afirmação de ser o ato de utilização da prestação, manifestação de vontade. De fato, não exigindo a própria lei que a declaração de vontade para concluir negócio jurídico seja expressa (arts. 1079 e 1084, § 151 BGB), podendo ser tácita ou pelo silêncio, ou ainda através de volitivas Willensbetätigungen, denominadas por Pontes de Miranda de manifestações simples de vontade, porque são adeclarativas no sentido de ser o ato simples indício de vontade, não haveria aparentemente, maior dificuldade em admitir-se esta concepção. Mas a dificuldade não está na maneira como se exterioriza a vontade, senão que está na própria vontade, porque «o que importa para se saber se a declara- ção de vontade ou ato volitivo adeclarativo pode ser suporte fáctico de negócio jurídico é precisar-se se a vontade, que ali se declara ou que aqui se manifesta, contém a de estabelecer o negócio jurídico ou o suporte fáctico de negócio jurídico. Não há negócio jurídico sem vontade de negócio. Vontade de negócio e não só declaração de vontade» (25).

O negócio jurídico supõe, como condição de existência, a exteriorização de vontade negocial. A caracterização desta é, no entanto, ainda hoje, discutida. Assim, como pressuposto de existência da vontade negocial e portanto do negócio jurídico, exigem alguns autores, entre os quais Lehmann, von Tuhr, Pontes de Miranda, a consciência da manifestação (Erklärungsbewusstsein) ou a vontade de manifestar (Erklärungswille) ). Outros, como Enneccerus-Nypperday, Manigk, couten tam-se com a existência de uma consciência da exteriorização. Por outro lado, persiste a antiga dicotomia: primado da vontade sobre a declaração ou primado desta sobre aquela, e se pergunta: é necessário que por trás da manifestação ixista uma vontade negocial ou basta, para a vinculação, tão somente a manifestação? Quanto a este ponto há-se de concordar com Pontes de Miranda quando diz que «à tese do primado da declaração formal sucedeu a antítese da teoria da vontade, a que havia de se seguir a síntese, e esta tinha de partir de que a vontade é que há de primar, salvo onde fazê-la mais forte que a manifestação poria em risco a segurança do tráfico (26). Aqui está presente, em última análise, o reconhecimento de um segundo princípio do direito privado, ao lado do princípio da autonomia da vontade e que é o da proteção à confiança, que a seguir será examinado.

Quanto à vontade negocial, há ainda os que a caracterizam como sendo a vontade dos efeitos jurídicos. Mas isto não basta; de um lado, porque os efeitos jurídicos são efeitos de fato jurídico e por conseguinte, de suporte fáctico em que há vontade e da lei; de outro, porque muitos efeitos se produzem sem terem sido queridos e mesmo contra a vontade dos manifestantes. Queridos ou não, os efeitos são aqueles que a lei atribui a determinado fato jurídico. «Ora, a vontade pode não ser dos efeitos jurídicos; quem compra não pensa na actio empti; pensa em vir a adquirir a coisa, o que não depende só da compra e venda; pensa no negócio jurídico; e ainda que pensasse em $\mathrm{X}$ efeitos jurídicos, a declara ç̃̃o ou manifestacão de vontade só irá obter aqueles que resultarem do negócio jurídico mesmo» (27). A vontade dos efeitos é portanto inseparável da vontade de negócio; quem quer certos efeitos jurídicos precisa querer também o negócio jurídico (intenção de realizar negócio). Assim, por von- 
tade negocial apta a ser suporte fáctico de negócio jurídico se há de entender em 1. lugar, a vontade de realizar negócio, e só posteriormente a dos efeitos. Negócio jurídico existe, em existindo apenas aquela e foi não sério, mas inexiste na hipótese inversa. No que se refere à manifestação, há de se exigir seja ela consciente. Quem manifesta vontade, sem consciência do seu siginificado negocial, não pratica negócio jurídico, por exigência do princípio da autonomia da vontade.

Os autores que adotam a posição que ora examinamos, sublinham todos a necessidade de se desligar «de um falso psicologismo no campo da doutrina da declaracão de vontade» (28) e a crítica feita por Siebert a Haupt e Larenz é a de que, se não vêem no ato de utilização de prestação existencial, manifestação de vontade, é porque partem de uma concepção demasiado individual-psicológica de declaração, quando em verdade, «aquele que se utiliza da prestação existencial está, via de regra, consciente de que se trata, ao entrar no bonde, de outra coisa do que quando aceita, no domingo, o convite de amigo para passeio pelo campo. Em outras palavras, o partacipante do tráfico, aquele que se utiliza do bonde, por exemplo, tem consciência das conseqüências jurídicas e econômicas de sua conduta. Tem por isso, via de regra, a vontade de originar um determinado efeito negocial e com isto também a vontade negocial, pressuposto regular de uma declaração de vontade» (29). Sublinha ainda o mesmo autor não se tratar de uma ficcão de declaracão de vontade, mas de valorização jurídica de uma conduta fáctica.

Há aqui aparentemente uma certa contradição, porque, ou se trata de uma conduta que realmente manifesta vontade, portanto, de manifestação tácita de vontade ou manifestação simples de vontade, ou de uma conduta à qual a lei ou os usos do tráfico atribuem um significado negocial. E, de fato, a esta conclusão acaba por chegar Siebert, ao analisar a hipótese formulada por Haupt através do seguinte exemplo: um aviador amador, sem o saber, pousa seu avião num aeroporto comercial, incorrendo por este fato, na obrigação de pagar a correspondente taxa de pouso. Aqui, embora a conduta do indivíduo manifeste uma determinada vontade negocial, não tinha ele consciência deste fato, nem a intenção de manifestar tal vontade, de modo que, segundo as regras da lei civil, se há de concluir que negócio jurídico não houve. Esta conclusão, no entanto, segundo Siebert (e também segundo Haupt, mas por outras razões) não se adapta as relações de prestação existencial no campo do tráfico em massa, porque «a tipicidade social destas relações, a necessidade prática de execução dos casos singulares sem atritos, seu caráter de massa dão ensejo a que se atribua importância maior de massa, dão ensejo a qué se da relação, especialmente aos círculos do tráfico partícipes da relaça, especta ao destinatário da manifestação, do que ao interesse do ajo sigte em não ficar vinculado a sua conduta exterior,

nificado negocial não tinha consciência» (30).

O ter evidenciado desta forma as especialidades do tráfico em massa é, segundo o mesmo autor, o grande mérito da teoria das relacôes contratuais fácticas, embora não se preciteoria das relar aquela conclusão, negar, com Haupt, que a se, para chabelece em virtude da conclurelação de prestação não se estabelece em virtude $\mathrm{BGB}$ a conssão de negócio jurídico. Isto porque no próprio BGB a consciência da manifestacão e a vontade negocial não são pres ciência da polutos da manifestação de vontade, pois em cersupostos absolutos da partes, tos casos, a lei atribui a conduta exterior de ú sem atencão a sua vontade interior, um conteńo de declarac̃̃o neçal O exemplo citado por Siebert é o da continuação negocial. ção do uso da coisa pelo locatário, que ve o locador, dentro ção da locação por prazo indeterminado se o locador, disa não de duas semanas findo o prazo da locação, outra coisa não declarar (BGB \& 568, Código Civil, art. 1195). Em casos codeclarar (BGBém há de alegar falta de consciência ou de vonmo este, ninguém há de alegar saltacão seja impugnável, entade negocial, embora aquela situação seja impuira que nestre outras razões, por exemplo, por erro. De maneira que nesta hipótese manifestação de vontade existe, independentementa hipótese, manifestação de vontas subjetivos; a validade já é te da verificaçã outro problema.

Mas, ainda outra hipótese existe, no direito alemão, em que vontade interior (consciência e intenç̃a) não é pressuque a vontade interior consciência negocial. A partir do § posto da manifestação de vontade negociaco a nue não temos 157 BGB que contém regra de interpretação que não temos em direito civil brasileiro mas sim em direito comercial no em direín cón subjetivismo da art. 131 do cód regra do $\$ 133$ e art. 85 do código civil, segue a boa fé, atencontratos devem ser interpretados como o exige a boa le, atendendo-se aos usos e costumes», a jurisprudência alemã construiu, relativamente ao valor objetivo de declaração de uma truiu, relativán ussim formulado: «recoconduta, o principio por ela mito deinhece-se, no estado atual do direito, que cada um tera a sua xar valer os seus atos contra si mesmo, não como era cointenção segundo a vontade interior, não manifestada, mas cointenção segundo entendidos pelos usos e costumes do tráfico, isto é, pelas concepções do tráfico». Ou ainda: «decisiva năbé vontade interior do agente, mas sim, de como sua conduta valorizada pelos usos e costumes e concepções dominantes do tráfico». - Disso se conclui que «o fundamento direto da responsabilidade não é uma vontade dirigida a esta respon- 
sabilidade, mas o princípio da boa fé e o da proteção à confiança» (31).

Reconhece-se aqui vigência ao princípio da proteção à confiança o qual, segundo as palavras de Staudinger (32) é hoje da mais alta relevância devido à «despersonalizacáo do moderno tráfico negocial». Incide ele sobre as relaçôes jurídicas negociais ao lado da autonomia da vontade e visa, limitando-a, proteger a segurança do tráfico. «A autonomia privada é de um lado, o primum principium para todas as situações jurídicas de direito privado. Mas de outro, uma compreensão global do direito privado seria impossível, se se negligenciasse seus outros fatores, porque as regras que deles emanam atingem profundamente a autonomia privada, completando e limitando-as» (33). Estes outros fatores são precipuamente a boa fé e a proteção à confiança.

A idéia da proteção a confiança constitui, segundo Staudinger, o segundo princípio da ordem jurídica privada porque também dela e não só da autonomia privada, podem resultar vinculações jurídicas e responsabilidade no tráfico jurídico, risco que corre todo aquele que dele participa. Assim, enquanto em muitas hipóteses alguém se obriga porque quis obrigar-se, manifestando expressa ou tacitamente esta vontade negocial, em outras, pode alguém obrigar-se porque se conduziu de forma tal que outrem desta conduta depreendeu uma vontade negocial e nela confiou. Na primeira hipótese, vontade negocial existe, e o fundamento da vinculação é o princípio da autonomia da vontade; na segunda, vontade negocia de fato pode não existir, mas um vínculo jurídico se estabelece baseado no princípio da proteção à confiança por isso que se disse que «decisiva não é a vontade interior do agente mas sim, de como sua conduta é valorizada pelos usos e costumes e concepções dominantes do tráfico». Trata-se portanto de conduta concludente (facta concludentia, já percebida e revelada por Savigny), espécie de manifestação tácita de vontade em sentido amplo, mas dela se distinguindo em sentido estrito, porque $o$ indivíduo responde pela sua conduta, mesmo que não tenha manifestado nem tenha tido intenção de manifestar vontade negocial, se de sua conduta se podia concluir ou alguém concluiu, vontade negocial, de forma que será tratalo como se tivesse tido essa vontade. Staundinger assim se expressa: «Responsabilidade pela confiança, em virtude de conduta concludente no tráfico jurídico se estabelece, quando uma parte se comporta no tráfico negocial de maneira tal que determinados terceiros, pressuposta uma orientação honesta e razoável, possam confiar em que aquela parte tenha tomado e exteriorizado determinada decisão ne- gocial, assim que exige a boa fé, seja aquela parte tratada como se tivesse declarado a correspondente vontade negocial» (34). E continua: «O fundamento aqui não é a existência de uma vontade negocial da parte obrigada, ainda que não declarada, mas, baseada no princípio da boa fé, a proteção à confiança de terceiro, que confiou na conduta daquela parte». Em verdade, de manifestacão de vontade aqui não se pode falar. Há uma presunção juris et de jure ou mesmo uma ficção de manifestação, mas somente quanto aos efeitos dela. «A equiparação à manifestação de vontade diz respeito aqui tão somente aos efeitos que se atribui a referida conduta, porque o fundamento de tais efeitos é totalmente diverso, repousando não na autonomia privada, mas no princípio da proteção a confiança» (35).

$\mathrm{Na}$ interpretacão da conduta concludente decisivo é o significado objetivo que os usos e costumes do tráfico lhe atribuem, porque somente quando este significado é unívoco é que se pode cogitar de responsabilidade pela confiança em virtude de conduta concludente.

Por outro lado, pode o indivíduo, tendo consciência do significado de sua conduta, ter interesse em evitar as conseqüências que dela resultam, o que ele obtém através de uma protestatio. A eficácia dela, no entanto, é limitada, o que aparece claramente quando se cogita de que há efeitos que a lei atribui a uma manifestação de vontade e que se produzem independentemente e mesmo contra a vontade do manifestante. Além disso a máxima «protestatio facto contraria non valet» impede que se possa pretender protestar contra um determinado significado da conduta, quando a conduta de fato é incompatível com a protestatio. O exemplo citado por Staudinger é o daquele que recebe livro para examiná-lo antes da compra e que corta as folhas ou faz apontamentos: tem-se que, por esse fato, expressou sua vontade de comprar, mesmo se protesta expressamente contra sua interpretacão.

Siebert entende então que o fato da utilização da prestação existencial, do qual nasce a relação jurídica de prestação, é uma conduta concludente que permite dela inferir-se vontade negocial. Com ele parece concordar Flume quando diz, criticando Larenz, que «a utilização da prestação oferecida em troca de uma tarifa é, exatamente devido ao seu significado social típico, um negócio jurídico» (36), porque as concepções dominantes do tráfico atribuem aquele ato um significado de manifestação de vontade negocial. Mesmo que no caso esta não exista, a obrigação se estabelece, baseada no princípio da proteção à confiança e não na autonomia da vontade. 
A conseqüência desta diversidade quanto ao fundamento da responsabilidade é a de que nem todas as regras relativas ao negócio jurídico tal como é concebido pela lei civil, ou seja, aquele que nasceu de manifestacão autônoma de vontade, são aplicáveis aos negócios jurídicos cujo objeto é uma prestação existencial. Assim, as regras sobre anulação de negócios por defeito de vontade tem uma aplicação restrita; a possibilidade de anulação por erro se exclui totalmente, porque, como diz Staudinger, «a admissão de manifestação tácita de vontade nesse caso, perderia seu sentido essencial, se o agente pudesse declarar que se enganara a respeito do significado que se poderia atribuir a sua conduta» (37), já que o fim visado não é a proteção da vontade individual, mas a confiança de terceiros. Esta construção, como o aponta Siebert, se adapta perfeitamente às prestacões existenciais em massa, porque no campo do tráfico em massa o suporte fáctico das regras sobre anulação por erro não se compõe, já que, como se disse anteriormente, a vontade individual não é valorizada: «as características e as finalidades individuais são niveladas, só tendo significacão jurídica os caracteres típicos e gerais. Tipificação e nivelamento são a expressão de supressão do momento volitivo. O destinatário da prestação se encontra numa situação típica; a identidade das relações jurídicas para todos exclui que se leve em consideracão a vontade inidvidual» $(38)$

Também a anulação por dolo ou coação não é de ser admitida porque só se protege, por definição, a confiança que terceiros, «honesta e razoavelmente» depositaram no significa do negocial de determinada conduta, e por isso afirma staudinger, que tais regras «não são necessárias». De maneira que está implícita a inaplicabilidade das normas relativas à anulabilidade por dolo e coacão. Siebert não se dá conta deste detalhe, apesar de também ter frisado que se pressupõe, na proteção à confiança, uma orientação honesta e razoável por parte daquele que confiou, pois afirma que «a idéia de direito da forca normativa dos usos e costumes do tráfico exige que se pesem os interesses do tráfico na execução dos casos singulares sem atritos e o interesse do participante individua em ser exonerado do vínculo negocial em virtude de deficiência de vontade. $\mathrm{Na}$ anulaç̃o por dolo ou coacão, o momento anti-jurídico pesa mais a favor da proteção do interesse in dividual» (39). Acrescenta no entanto que, referentemente às prestacões existenciais, tais casos dificilmente ocorrerão, porque o destinatário (o empresário) não conhece ou não poderá conhecer o dolo e muito menos o exercerá pessoalmente. Quanto a coação, que também raramente há de ocorrer, «a anula- ção é de se admitir sem restricões». Todavia, a razão está em Staudinger, porque quando há coação ou dolo, a hipótese de proteção à confiança, por definição, nem chega a se configurar, de modo que não se estabelece vínculo jurídico algum; há, isso sim, ato ilícito absoluto.

Em última análise, pode se afirmar que as regras relativas à conclusão de negócio jurídico que tem como suporte fáctico a vontade, não se aplicam aos negócios jurídicos que nascem em virtude de proteção à confiança, porque esta, e não a vontade, é que está a sua base.

No entanto, exceção se abre, às regras sobre capacidade, e neste particular, Siebert é evasivo dizendo que «as hipóteses de incapacidade praticamente, não alcancam maior importância, porque, ou, semelhantemente aos demais casos de utilização social típica de prestação existencial se desenvolverão sem atritos, ou não chegam a se tornar agudos (...) quando a outra parte, reconhecendo a incapacidade recusa a conclusão de contrato» (40). O BGB possui, porém, uma disposição chamada de «parágrafo da mesada» (Taschengeldparagraph), § 110 , que facilita a solução desta hipótese, pois, de acordo com ele, «um contrato concluído pelo menor sem o consentimento do representante legal considera-se desde o início válido, se o menor satisfez a prestação contratual com meios que, para esse fim, ou para livre disposição lhe foram cedidos pelo representante ou, com o consentimento deste, por terceiro». Segundo Siebert, esta, ou a exigência da autorização, estarão satisfeitas na maior parte dos casos, mas admite, em última instância que os contratos que tem por objeto uma prestação existencial possam ser declarados nulos por incapacidade, hipótese que se resolve, se a prestação já foi utilizada, através do enriquecimento sem causa, pois que não pode ser devolvida.

Segundo Siebert, em suma, juridicamente explicável é tão somente a impossibilidade de anulação por erro. Mas, repita-se, sem razão, pois como se viu, na espécie em que incide o princípio da protecão à confianç, também, e por definição, não se pode admitir a anulabilidade por dolo ou coação. Quanto a nulidade por incapacidade absoluta, que teoricamente quanto àquela espécie é impossível, mas que, no campo das prestações existenciais é de se excluir, Siebert fica de certo modo a meio caminho, tentando explicar o jurídico através do que mais ocorre na prática, o que não representa nenhuma solução jurídica. Este é assim o ponto que a concepç̃o da relação jurídica de prestação existencial como negócio jurídico nascido da proteção à confiança não resolve, é o ponto fraco desta concepção. 
A maioria dos autores que adotaram o ponto de vista de ser o ato existencial negócio juxídico, de uma forma ou de outra, concordam em que tal ato não pressupõe vontade negocial. Assim, além de Siebert, Esser: «a integração dogmática da relação tipificada de prestação existencial no nosso sistema só pode ser feita através de tratamento analógico de atuações volitivas que fundamentalmente prescindem de manifestação, como uma manifestação» (41), e Ballerstedt: «é errôneo crer-se que o manifestante é obrigado porque queira obrigar-se; trata-se em última análise, de quais as conseqüências que a lei atribui a uma determinada conduta» (42). Em conseqüência, apontam todos a impossibilidade de se aplicar as regras sobre negócios jurídicos tais quais são postas pela lei civil, sublinhando a necessidade de utilização de métodos de interpretação tais como analogia e restrição, de acordo com as particularidades de cada caso, já que sob a denominação geral de ato existencial se abrangem em realidade uma série de atos que diferem entre si, e ainda a necessidade de modificação do direito através de construção doutrinária e jurisprudencial que, sem ser contra legem, lhe atribua uma dimensão mais social.

Esta mesma orientacão, de ser o ato existencial negócio jurídico, é adotada ainda por Pontes de Miranda, cuja exposição no entanto não é clara e as vezes, contraditória (43). Assim, por exemplo, após ter afirmado que «a concepção do tráfico recebe alguns atos humanos como se fossem manifestações de vontade», diz que (crítica que se refere diretamente a Larenz, mas que se estende às opiniões que acabamos de expor), «a afirmaç̃a de o moderno tráfico em massa implicar que se assumam deveres e obrigações sem que se tenha querido manifestar vontade, é falsa... Não se pode dizer que o ato de entrar no ônibus, ou no bonde ou de ter de pagar o preço não seja manifestacão de vontade. O que se passa é que quase todo o conteúdo da manifestação de vontade já estava pré-estabelecido, e não se pode deixar de ver na vinculação ou no direito a ser transportado, eficácia de negócio jurídico típico». Surge então a dúvida: o ato de utilização da prestação é manifestação de vontade ou é ato ao qual a concepção do tráfico atribui tal significado.

Quanto ao aspecto que diz com a nulidade e anulabilidade dos atos existenciais, diz Pontes de Miranda: «o Estado teve de regrar o convívio humano, devido ao crescimento das populações, das empresas técnicas e a impossibilidade mesma de se identificar cada um dos figurantes. O direito público intrometeu-se e estabeleceu os contratos de exploração de serviços públicos, em que não se deu importância ao ato huma- no como suscetível de deficiência (nulidade, anulabilidade). Em vez disso, considerou o ato humano como suficiente e sem deficiência». A caracterizacão nestes termos serviria antes à conclusão de ser o ato existencial ato-fato; mas esta objeção é refutada em seguida pelo próprio autor: «quem foi no trem, no bonde, no ônibus, na barca ou na balsa, negociou. $\mathrm{O}$ direito tem tal ato como ato humano, que é, embora o repute não suscetível de se lhe investigar a deficiência».

Então, de um lado excluiu-se a nulidade e a anulabilidade porque o direito considera $o$ ato suficiente; mas por outro lado, afirma Pontes de Miranda que o menor e o louco podem negociar porque «o direito público teve que atender a que o louco e o menor de 16 anos precisam de transporte como as outras pessoas. Entre vedar-lhes a utilização dos transportes e considerá-los com o consentimento dos pais, tutores ou curadores, ou do Estado, se os não tem, o direito preferiu o segundo caminho». Então, ainda segundo o mesmo autor, quem aceita (pela utilização) não é o incapaz, mas o representante legal e na ausência deste o Estado («por necessidade pública ou por negligência»), entrando o ato do incapaz no mundo jurídico, como ato-fato.

Parece fora de dúvida que Pontes de Miranda vai longe demais; como admitir-se um ato-fato que necessite de consentimento? Por outro lado, não se entende em que sentido é o ato suficiente, não suscetível de se lhe investigar a deficiência: assim é porque se trata de ato-fato e então não há necessidade de consentimento, ou porque há presunção absoluta de consentimento e então o ato de utilização da prestação não é o ato-fato. Uma coisa exclui a outra; há duaș soluções, é preciso adotar só uma.

Ainda outra afirmação que não se enquadra no contexto da exposição de Pontes de Miranda é a de que «o cartão, o bilhete, a ficha ou outro recibo sem nome é expressão de que se abstraiu do apresentante, de jeito que não se pode pensar em invocacão de regras jurídicas sobre incapacidade e invalidade por erro de pessoa ou por dolo. A violência e o dolo ou o próprio erro só seriam matéria para discussão da posse. O cartão é para alguém dentre todos...» Se se abstraiu dos figurantes de jeito a não se poderem invocar, por isso, as regras sobre incapacidade e deficiência de vontade, porque presumir o consentimento do representante legal (e fingir representante legal na pessoa do próprio Estado)? Pontes apresenta aqui mais uma solução para o problema da incapacidade. Quanto à anulabilidade nada se diz sobre poder ser anulado o consentimento presumido do representante legal. 
Parece-me que, no fundo, o que Pontes de Miranda não consegue é explicar porque o ato de utilização da prestação não é, em todos os casos, ato-fato. Desta conclusão ele de certa maneira foge, porque, não admitindo que o negócio jurídico possa surgir sem vontade negocial, mas reconhecendo que «a vida de relação procede a certa abstratização dos figurantes dos negócios jurídicos em que há o contato com o alter, ou com o treguês, e dos figurantes do contrato de transporte», ela seria a única coerente.

\section{b) A concepção de Karl Larenz e a concepção do ato exís}

\section{tencial como ato-fato}

Uma referência à concepção de Larenz já foi feita anteriormente (pg. 15 e 16). Segundo este autor, o usuário que entra no ônibus «tem, neste momento, via de regra, apenas a vontade de sex transportado ao destino e não cogita de concluir previamente um contrato com a empresa. Estará todavia, disposto a assumir as conseqüências jurídicas de seu ato, e por isso, a pagar o preço tarifário. Só que, para o nascimento da relação de transporte é indiferente se ele tem esta vontade ou se reconhecidamente não a tem» (44). Renunciando-se recorrer a uma ficção, o fundamento da responsabilidade só pode ser encontrado, segundo Larenz, na convicção jurídica geral de que aquele que se conduz da maneira estabelecida, «social típica», qual seja, utilizando uma prestação existencial oferecida publicamente, por este fato se vincula juridicamente, sem considerações sobre ter sido ou não esta a sua vontade. A relação de prestação «nasce por força da convicção jurídica do tráfico, através da utilização de fato da prestação existencial como conduta social típica». Por isso é de se excluir a possibilidade de anulação do ato assim como a exigência de capacidade negocial do agente, mas somente a «aptidão para reconhecer o significado social típico da conduta». Em contraposicão há de se exigir que «o agente tenha consciência das circunstâncias das quais resulta o significado social típico de sua conduta, portanto por exemplo, que saiba que está se utilizando de um meio de transporte ou que o estacionamento que utiliza é sujeito a pagamento. Só então tem ele a possibilidade de orientar sua conduta em função dos efeitos, o que constitui exigência do princípio da autonomia privada. Dever conhecer é o mesmo que conhecer. Neste sentido tem de ser a conduta, no seu significado social típico, imputável ao agente» (45).

As regras jurídicas sobre contratos se aplicam ao desenvolvimento da relação jurídica, mas não podem aplicar-se ao seu nascimento, já que não havendo vontade, não há consenso.
Esta concepção suscita certas dificuldades, como a de saber o que significa o ter de ser a conduta, quanto ao seu significado social típico, imputável ao agente. O louco ou o estrangeiro que acaba de chegar ao país de costumes e concepções totalmente diversas não tem condições de conhecer tal significado e portanto não pode orientar sua conduta em funcão dos efeitos. A pergunta que surge é a de se saber qual a conseqüência disso: seria o ato nulo na primeira hipótese e anulável na segunda? Sob pena de perder sentido toda a construção, a solução só pode ser no plano da existência, de forma que se há de dizer que vinculação jurídica não houve, a obrigação não nasceu; solução de certa forma no mundo fáctico impraticável, mormente se a prestação foi efetuada pela outra parte.

A outra dificuldade está em que, de acordo com Larenz, sempre que o passageiro, antes da utilização do transporte, adquire bilhete ou passagem, a fonte da obrigação repousa no contrato, o que acarreta a conseqüência de incidirem todas as regras jurídicas sobre conclusão de negócio jurídico. Ora, uma diferenciação tão nítida e profunda do ponto de vista jurídico não se justifica para duas situações de fato praticamente idênticas. O meio de transporte pode ser o mesmo, o mesmo o preço e a duração da viagem, apenas diverso o regulamento por ser diversa a empresa transportadora. Numa situação se exigirá capacidade, permitir-se-á anulação por erro, etc. E noutra nada disso ocorre.

Em verdade, esta dificuldade é mais profunda, atingindo as prestações existenciais na sua totalidade. É a extrema dificuldade e quase impossibilidade de tratar unitariamente todas as espécies com a finalidade de sistematizá-las. Elas diferem uma das outras tanto em si mesmas (compare-se os atos que visam obter o fornecimento de água ou luz com os que visam atender as necessidades de vestuário, alimentação ou transporte), quanto à forma sob que se apresentam, oferecidas algumas pelo Estado, direta ou indiretamente, outras a das prestações; mas mesmo que se admitisse, com 'Larenz, ser cargo ou critério exclusivo dos particulares ou com alguma in terferência do Estado através de limitações ou tabelamento de preços.

A concepção de Larenz é insustentável exatamente porque, em lugar de simplificar as hipóteses para permitir uma sistematizaç̃o, ainda que em termos gerais, diversifica-as ainda mais, dificultando uma análise global. Na hipótese acima figurada poderia ver-se simplesmente uma inversão na ordem das prestações; mas mesmo que se admitisse com Larenz, ser a fonte em certas hipóteses contratual, ter-se-ia de reconhecer 
que tal contrato tem características específicas, porque se trata de um negócio do tráfico em massa; por isso não lhe seriam aplicáveis, sem mais, as regras da lei civil sobre conclusão de negócio.

A concepção do ato existencial como ato-fato aproximase muito da concepção de Larenz e pode-se mesmo afirma que, quando diz que para o nascimento da relação de prestação é indiferente o saber-se se o indivíduo tinha ou não a vontade de concluir negócio, está a dizer que a fonte daquela relação é um ato-fato.

Quanto ao ato-fato é preciso ter-se presente que não se trata de uma categoria jurídica em que não está presente a vontade, mas sim, daquela categoria em que não se valoriza a vontade que pode existir ou que de fato existe no ato. Abstrai-se dela e o ato entra do mundo jurídico como fato, por que ao direito só interessa o resultado do ato. «Mais rente ao determinismo da natureza, o ato foi recebido pelo direito como fato do homem, pondo-se entre parênteses n quid psíquico, 0 ato, fato (dependente da vontade) do homem, entra no mundo jurídico como ato-fato jurídico» (46).

Segundo as palavras do mesmo autor, o ato (existencial) é suficiente.

Assim é, de um lado, porque no campo das prestacões existenciais em massa se abstrai do indivíduo e de sua subjetividade, e por outro, porque as concepções do tráfico ou a própria lei ou regulamento de determinado serviço existencial, têm ou prevêem expressamente que o ato é suficiente. Por isso é que se pode denominá-lo de conduta social típica.

Este ato típico é o elemento de conexão indispensável e suficiente para incidência do regramento jurídico. Basta entrar no ônibus, estacionar o veículo no parque especialmente destinado a esse fim ou aterrisar no aeroporto e se estará obrigado a pagar a tarifa correspondente; basta pegar a mercadoria exposta pela loja ou supermercado para se ter de pagar o preco pré-fixado.

É perfeitamente possível ver-se em todos esses atos típicos, atos-fatos; qualquer criança pode praticá-los e o regra mento em todos os casos é cogente, no sentido de que as condições de prestacão e as conseqüências do ato são unilateralmente fixadas, não dando margem a discussão.

Mesmo aquele que pleiteia o fornecimento de energia elétrica ou de água através de um pedido de ligação, se conduz de forma social típica e o ato previsto pelo regulamento da companhia fornecedora como requisito ou pressuposto da prestação, é suficiente, não suscetível de deficiência. E o mesmo vale para a hipótese em que o indivíduo antes de se utilizar do transporte, adquire bilhete. Todo o ato no campo das prestações existenciais em massa é ato típico; uma vez praticado dentro dos moldes pré-estabelecidos, ele é suficiente. O ato-fato existe (e produz certos efeitos determinados em lei) ou não existe; o ato existencial ou é praticado segundo o padrão e é suficiente, ou não o é e não é apto a produzir o resultado a que se visa.

Por definicão, está o ato existencial mais rente ao determinismo da natureza, dando-se maior relevo à necessidade do que à vontade, pois decisivo é o que o indivíduo precisa e não o que ele quer.

Semelhantemente ao que diz Larenz, também ao desenvolvimento da relação nascida de ato-fato, se aplicam as regras jurídicas sobre negócio jurídico (por exemplo, as regras sobre vícios redibitório). Por isso, e à mingua de outra denominacão mais apropriada, pode se chamar tal relação de «contrato», sobre o qual não incidem e são inaplicáveis, as regras jurídicas sobre negócio que tem como elemento do suporte fáctico a vontade negocial. Ocorre que, esvaziado de seu conteúdo, a vontade, sobrou apenas, mas sobrou, o mecanismo do negócio jurídico.

\section{III - CONCLUSÃO \\ 1 - "O Futuro do Direito Privado"}

A problemática dos atos existenciais, como penso ter ficado evidenciado, é extremamente complexa e de grande alcado deoria dos negócios jurídicos e os próprios fundamentos da ordem jurídica privada. Assim Spiros Simitis, indo demasiado longe, segundo Larenz, pretendeu ver neles a expressão da transformacão da funç̃a social do direito privado, especialmente do contrato (47). É no entanto inegável, e a ampla discussão que se estabeleceu na Alemanha o prova, que aparecem aqui novas tendências jurídicas, suscitadas pelas transformações gerais da vida humana. O mundo social não é estático, e o direito, como processo social de adaptação ou como instrumento de ordenação da realidade social utilizado pelo Estado para manter ou desenvolver o Bem Comum não pode ser concebido cópo atual se caracteriza pelo processo acelerado de transformações, devido à rapidez com que hoje se pode por em prática as novas descobertas científicas e o direito não pode ficar alheio sob pena de se tornar ineficaz. Por isso ñ̃o só a necessidade de um trabalho legislativo mais acelerado se impõe, mas também a pesquisa e a elaboração doutrinária precisam ser intensificadas. 
É forçoso reconhecer que ao lado do campo de atuação próprio e específico do negócio jurídico, outro campo começou a surgir: o do tráfico em massa, do qual as prestações existenciais constituem uma parcela significativa e que só tende a se ampliar e que possui certas características que o especificam: o volume de transações, a despersonalização das relações jurídicas, as restrições ao princípio da autonomia da vontade e a grande necessidade de segurança.

O negócio jurídico, como instrumento da autonomia da vontade não pode ser utilizado nesse campo sem algumas modificações ou adaptações. Isto perceberam todos os autores que examinaram a natureza jurídica dos atos existenciais. I o problema que surgiu foi o de se saber se tais modificações são possíveis, no sentido de as comportar a teoria do negócio jurídico sem desnaturar o instituto. Quanto aos atos existen ciais, a concepção que vê neles atos-fatos, responde negativamente a esta pergunta.

Neste trabalho tentei mostrar que a modificação é possível através do reconhecimento de vigência, no direito privado do princípio da proteção à confianto em massa ocorre aquilo que Pontes de campo do tráfico fazer-se mais tráfico mais forte a vontade põe em risco a segurança do

Não se trata de admitir, conforme a crítica de Bidlinsky (48) que haveria dois campos distintos incidindo num deles o princípio da autonomia da vontade e no outro, o da proteção a confianca. Ambos incidem em todas dicas de direito privado, com maior ou menor intensidade conforme a maior ou menor necessidade de segurança do tráfico que se mede pelo grau de interesse público presente. ́́. preciso não perder de vista que o princípio da autonomia da vontade também atende a da é a segurança do individuo segurança, mas isso, onde a necessidade isso, onde a necessidade de segurança do tráfico é maiox do que a do indivíduo porque este, enquanto participante do tráfico obtém sua segurança daquela, há de incidir com maior intensidade o princípio da proteção à confiança.

Como mostra o professor Raiser em excelente conferência realizada em 1971 na Sociedade Jurídica de Berlim, intitulada «O F'uturo do Direito Privado» (49), se, por um lado, se reconhece com toda a amplitude a autonomia privada e mesmo se lhe confere maior garantia hoje através da elaboração de um naior de personalidade, de outro direito vem-se valorizando sempre mais a «idéia ética do indivíduo como membro»e de sua conseqüente responsabilidade social.
Esta idéia se manifesta no alargamento do princípio da boa fé, na complementação da teoria das declarações de vontade pelo princípio da proteção à confiança, na extensão de efeitos contratuais a relações jurídicas sem concordância total de vontade (sem consenso) e no anseio por uma justiça material nos contratos. «Não resta dúvida», prossegue Raisex, «de que se consumou uma modificação essencial no direito privado quanto ao seu conteúdo e também no método de aplicação do direito ou, mais geralmente falando, no seu espírito. O sistema se mostrou, naturalmente a custa de sua unidade interna, suficientemente flexível para se adaptar a concepções e necessidades profundamente modificadas».

Mas, se de um lado assim é, de outro, dado o aumento e a intensificação dos direitos de intervenção e controle do Estado em razão da pressão de suas tendências socializantes e previdenciais, pode-se falar de uma perda de função por parte do direito privado, de um estreitamento do seu âmbito de aplicação. Isto se manifestou claramente primeiro no direito do trabalho e depois no direito econômico, os quais no início do século ainda pertenciam ao direito privado, mas, nos últimos 50 anos, se independizaram, tornando-se ramos do direito à parte. Ainda segundo Raiser, manifesta-se também no que se chamou de "direito administrativo privado" ou seja, o fenômeno da utilização, pela administração pública, por razões meramente instrumentais e de oportunidade, de formas e institutos de direito privado, cujo campo de aplicacão assim aparentemente se alarga, quando em verdade se restringe, porque o direito privado é apenas «tomado emprestado» para fins que lhes são alheios e informado por princípios de direito público.

Tudo isso, mostra, segundo Raiser, que «o direito privado, quanto ao seu conteúdo espiritual não está enrijado, mas quanto ao seu campo de aplicação, ao que parece, se encontra em retirada». Surge então a pergunta de se saber se esse processo é irreversível ou de saber qual a função que o direito privado é hoje e poderá ser no futuro, chamado a exercer. Aqui é preciso atentar para a circunstância de que apesar de me referir e de se referir Raiser a direito público e direito privado como se entre eles houvesse uma nítida distinção, esta todavia não é pressuposta, pois como diz aquele autor, esta distinção não constitui uma exigência de lógica jurídica mas significa apenas uma tentativa de ordenar utilmente complexos de normas e de compreendê-los segundo a sua aplicação.

Para que o direito privado se mantenha atuante, dois são os pressupostos que, de acordo com Raiser, se hão de exigir. 
Em primeiro lugar, que se mantenha as concepções de liberdade, auto-determinação e responsabilidade individual da pessoa, porque sem elas não se pode conceber um direito privado. Em segundo lugar, é preciso que ele não se isole nas suas concepções clássicas por receio de perder sua identidade, mas que se proponha formar e ordenar, em cooperação com o direito público, aquele campo que Raiser denominou de público, porque, não obstante nele atuarem preponderantemente pessoas ou organizações de direito privado, esta situação é informada por princípios de direito público e dirigida a fins públicos. Esta tarefa só será realizável se levar em conta a multiplicidade de setores de vida e de necessidade de uma sociedade industrial, o que significa que não poderá fixar seus institutos em uma só função social, mas ao contrário, deverá visar a multiplicidade de funções. Trata-se de utilizar simultaneamente o mesmo instituto jurídico em funções diferentes, conforme as exigências do setor em que é empregado.

"Minha tese», diz Raiser, «é no sentido de que o grau de privatividade ou de publicidade de um campo de vida deve conduzir a diferenças juridicamente relevantes na função $e$ manejo de institutos jurídicos de direito privado, diferenças estas que devem ser reconhecidas mais claramente do que o foram até hoje». Este critério da publicidade não é novo e aparece já nos códigos através da tipicidade legal dos direitos reais e no direito societário, por exemplo, sem que isso signifique a interferência do Estado através de atos de autoridade. Raiser sugere assim que se estruture o direito privado segundo campos de função que correspondam a campos de vida típicos, utilizando como critério de distinção o grau de privacidade ou publicidade destes campos Quanto mais intensa a presença do conteúdo público, tanto mais intensamente vigirão, no manejo das normas e institutos do direito privado, ao lado ou em lugar dos princípios «clássicos» que se referem ao indivíduo e sua vontade, aqueles, novos, já mencionados, determinados pela idéia da responsabilidade social do indivíduo. Aplicando então este critério, Raiser distingue quatro campos em que o grau de publicidade aparece em sentido crescente. O das prestações em massa onde «os interesses tipificados de grupos passam a frente das relações e interesses individuais» ocupa o $2^{\circ}$ lugar, porque «as relacões jurídicas e os conflitos de interesse ganham, devido a sua tipicidade, significado público (não será talvez o contrário?) e tem de ser, por isso, tratadas juridicamente, apesar de com a utilização dos velhos institutos, segundo padrões diversos» (31). Aqui se observa a tipificação e standartização das relações contratuais (semelhantemente a que ocorreu com o direito do trabalho que por isso se separou das relacões privadas e individuais de serviço reguladas rou dá Código Civil); as prestaçôes oferecidas não visam satisfazer necessidades individuais, mas «necessidades notul clás grupos inteiros de consumidores. O direito contratual clássico tinha de tolerar modificações significativas e ampliaçoe sico tinha dato no que refere ao para a proteção dos consumidorílicas, quanto ao que diz resnascimentringem basi-

peito a determinação do seu conteúdo e que restringem
camente e em muito, o princípio da autonomia privada».

A luz destas considerações e aceitando o critério proposRaiser, voltemos às duas concepções de ato existencial anteriormente expostas.

As modificacões que se operaram no campo do tráfico masa relativamente ao direito contratual clássico são em massa sobrado do contrato (negócio tais, que se peu jurídico bilateral) apenas o mecanismo, esvazião do seu conteúdo. Exemplos mais significativos disso são os chamados contratos de adesão, as condições gerais de negócio e os dos contratos de por objeto a prestação de serviços existencontratos que tem por objéteses do princípio da autonomia ciais. Em todas estas hipoteses, do princípio da contratar (e da vontade só ficou a escolha inicial de

mesmo isso pode ser posto em dúvida).

Especificamente quanto a natureza juridica dos atos existenciais, a opção é dupla: ou se trata de negocio juridico informado pelo princípio da proteção à confiança, ou de atosfatos.

Quanto a primeira, a questão pendente que não foi resolvida é a que diz respeito a capacidade negocial, porque segunde admitir-se a possibilidade de nulidade do do ela, haveria de adme não corresponde às conato por incapacidade absoluta, o que nao corresponde as concepções dominantes do tráfico nem ao que de fato ocorre na prática, porque se permite que incapazes utilizem prestaçóes existenciais. Isto porque, como disse Pontes de Miranda, neste campo era preciso cogitar de todos e portanto, o grau de publicidade aqui presente é tão elevado que autoriza a que pulco mais uma modificação no regramen se tenha como operatos e por ele tolerado. Vale repetir que to positivo dos contratos e por ele tolerado. nos defrontamos aqui com um contrato ao nascimento do qual não se aplicam as regras jurídicas referentes a conclusão de negócio jurídico porque tal contrato não é informado pelo princípio da autonomia da vontade, mas pelo princípio da proteção à confiança e as modificações assim operadas no regramento de direito positivo

publicidade ali presente. 
Ao desenvolvimento da relação jurídica no entanto, se aplicam as regras referentes aos contratos, porque seu desenvolvimento obedece ao mecanismo próprio dos contratos.

Há, porém, limites para a modificabilidade dos institutos segundo a diversidade de funções que é chamado a exercer; uma fronteira para além da qual não se poderia falar de contrato ou tão vago e to é. Este seria assim uno naber o que de fado ato existencial assim um argumento em favor da concepcão do ato existencial como ato-fato. As transformações operadas no instituto do contrato por exigência do tráfico são tão es senciais, porque afinal, nega-se vigência ao princípio da autonomia da vontade e a própria vontade, os dois elementos definidores e caracterizados do negócio jurídico, que mais vale negar vigência também ao próprio instituto.

A questão permanece em aberto; as duas concepções são viáveis. Todavia, a que vê no ato existencial negócio jurídi co fundado na proteção à confianca parece-nos mais adequada aos princípios éticos que informam o ordenamento jurídi co, porque a concepção do ato-fato teria o inconveniente de ordem meta-jurídica, no sentido de que viria contribuir para uma visão filosófica, hoje difundida, do indivíduo massifica do ou do ser humano coifica niente é que Larenz exige que a (para evitar este inconve gente, no sentido de que qu a conduta seja imputável ao a gente, no sentido de que é necessário que ele possa orientá-la segundo o seu significado social-típico). Embora esta visão to nha sido conseqüência imora esta visão telução industrial e signifique no plano filosófico, da revopara uma liberã signifique apenas um estágio passageiro para uma liberação maior do indivíduo, no sentido de lhe permitir o gozo efetivo de uma liberdade concreta, a concepcão do ato-fato implica numa certa desvalorização da personali-
dade humana.

Opto por isso pela concepção do ato existencial como negócio jurídico informado pelo princípio do neE s. $\mathrm{E}$ porque esse princípio, como o disse Staudinger, vem adquirindo sempre maior importância devido a crescente despersonalização das relações jurídicas em nossos dias, creio ser initeressante proceder a mais alguns esclarecimentos a seu respeito.

\section{2 - O Princípio da Proteção à Confiança}

Em excelente trabalho publicado em 1941 na revista alemã «Arquivo para a Prática Civil», intitulado «Problemas bá sicos de uma renovação do direito contratual», (50) Walter Schmidt-Rimpler, propondo-se a uma análise de um ponto de

\section{6}

vista de política jurídica e não dogmático, examina o princípio da segurança do tráfico juntamente com o da segurança jurídica. Ambos atravessam, como princípios «técnicos», todos os outros princípios, denominados pelo autor de «materiais», no sentido de positivos e obrigam a admitir, como certos, determinados resultados que segundo os últimos, seriam errados.

A necessidade de seguranca do tráfico parte da constatação de que o tráfico entre os indivíduos, sua atuação recíproca e conjunta, é necessária para a coletividade, mas se tornaria impossível ou muito difícil, em casos especiais, pela aplicaç̃o sem excecões, daquilo que é certo segundo os princípios materiais. Ou seja, algo que, via de regra, é certo, torna-se errado no tráfico, por razões especiais que nele próprio se encontram. Assim, quem deseja adquirir uma posição ju-. rídica e preencheu os pressupostos gerais para tal, deve estar seguro de sua aquisição, mesmo que faltem certos requisitos de correção os quais não se pode verificar sem alguma dificuldade mas, em cuja existência, devido à aparência, se pode confiar e é permitido confiar com o emprego da diligência exigida segundo o tráfico. Neste sentido, princípio da segurança do tráfico, principio da proteção a confiança e princípio da aparência são idênticos. A confiança na aparência só é protegida enquanto e na medida em que permitido confiar nela. Somente quando a aplicação dos princípios materiais impedir praticamente a ordem em geral e o tráfico em geral é que os princípios da seguranca jurídica e do tráfico tem, pela vontade da coletividade, de passar a frente, mesmo que assim, ao indivíduo, se faça injustiça. Entretanto, ao trazerem desvantagens materialmente injustas para um que, em nome da segurança do tráfico fica prejudicado, trazem via de regra, como se trata de relação jurídica, vantagens a outrem. Assim, à desvantagem de um não corresponde só a vantagem da coletividade, mas também a vantagem individual do benefiado. Proteção à segurança do tráfico é sempre, na sua eficácia, proteção do indivíduo na aquisição, portanto, proteção de uma vantagem individual. É por isso preciso ter certa cautela ao invocá-lo, e SchmidtRimpler formula algumas regras para a sua utilizacão. É preciso assim que, sem a modificação por ele autorizada, o tráfico em geral se torne impossível. Porém, o que geralmente ocorre, é que o tráfico é tão somente dificultado (verificacão dos registros antes de uma aquisição, por exemplo). Nesta hipótese é preciso verificar se esta dificultação é tão onerante que, por ela, se deva desprezar o prejuízo injustificado de uma das partes. Aqui, papel importante cabe à freqüên- 
cia com que tais prejuízos ocorrem, já que constitui prejuízo menor para o tráfico como totalidade, se o participante dele só raramente e casualmente sofre uma desvantagem. Mas, em seguida, é de se examinar ainda se esta desvantagem pode ser justificada no caso concreto, por razões especiais que estariam na própria relação jurídica dos atingidos, se e porque estão no tráfico e, quanto mais fortemente a parte prejudicada pode ser responsabilizada pela confiança e fé que a outra depositou na aparência, tanto menor precisa ser a dificultação do tráfico. Ao contrário, na medida em que esta é mais forte, bastará uma justificativa mais fraca na relação interna.

A segurança do tráfico jamais poderá ser o princípio fundamental para a aquisição de uma posição jurídica: o fato de que segundo ela, aquele que quer adquirir uma posição jurídica deverá obtê-la quando falte um pressuposto via de regra necessário, mostra que se trata de um princípio que incide apenas em casos excepcionais.

Esta análise é inteiramente pertinente à problemática dos atos existenciais e demonstra que, com justeza, se pode considerá-los negócios jurídicos baseados na proteção à confiança. Se se permitisse que estes atos pudessem ser anula dos por deficiência de vontade ou declarados nulos por incapacidade, o tráfico seria grandemente dificultado. Por outro lado, sendo os usuários muito numerosos e as prestações existenciais a cargo de número relativamente reduzido de empresas, fazer-se justica ao interesse individual daquele acarretaria um ônus pesado para estas, ao mesmo tempo em que, por via de conseqüência, vindo em detrimento da segurança do tráfico, prejudicaria também o indivíduo. A frequiência dos prejuízos para as empresas seria muitíssimo maior do que a freqüência deles para os indivíduos, porque cada um seria por eles atingido apenas eventual e raramente. E por fim, no que se refere à justificação da proteção à confiança na relação in terna entre os figurantes, ela é plena, porque, onde o indivíduo se comportou segundo o padrão de conduta típica, a outra parte está plenamente legitimada a confiar em que tenha querido o resultado que através daquela conduta, normalmente se sói obter.

Com isto, a problemática dos atos existenciais não está solucionada, (mesmo porque, além das apontadas, ainda outras soluções são possíveis). A grande dificuldade que resta é a da própria definição de ato existencial sem a qual não se pode delimitar o campo em que se hão de autorizar as modificações às regras gerais. Isto por sua vez é imprescindível pois, como disse Schmidt-Rimpler, o princípio da proteção à segurança do tráfico não é princípio geral, mas só deve ser admitido em casos especiais. Os atos existenciais são casos especiais e não devem ser confundidos com os que não o são.

Siebert (51) aponta as seguintes características que especificariam o ato existencial: é preciso que se trate de um negócio do tráfico em massa que não deixa margem a configuração individual e cuja conclusão repousa na conduta concludente ou social típica; que exista identidade com um grande número de relações de prestacão iguais; o anonimato e a impossibilidade de individualizar os figurantes e o conteúdo contratual; que seja vital para a coletividade. Neste campo se compreenderiam então: a utilização dos meios de transporte público, utilização da prestacão de água, gáz e energia elétrica, utilização de estacionamentos públicos, portos e aeroportos e todos os negócios entre os grandes magazines que oferecem o necessário à alimentação, vestuário e habitação, e o consumidor.

A finalidade do presente trabalho foi antes suscitar o problema do que resolvê-lo. Foi também a de, através dele, problematizar a teoria clássica do negócio jurídico como um instituto que necessita e tolera modificacões no seu regramento e conteúdo segundo a função que é chamado a exercer. $\mathrm{Na}$ medida em que esta função apresenta maior conteúdo de publicidade, na medida portanto, em que se afasta da função para a qual foi concebido, o princípio da autonomia da vontade, que segundo esta o informa, há de ser substituído pelo da protecão a confiança que visa a segurança do tráfico e que não é um princípio estranho ao direito privado, mas, pelo contrário, o integra, completando aquele. Partindo da idéia da responsabilidade social do indivíduo, tem posição de destaque na moderna democracia social, assim como o princípio da autonomia da vontade teve seu maior destaque na democracia liberal.

\section{IV - JURISPRUDÊNCIA}

Alguns casos foram julgados pelos tribunais alemães com base na teoria das relações contratuais fácticas. Dentre eles, o mais citado, por ser o mais significativo, é o chamado «caso do estacionamento» (Parkplazfall), decidido pelo BGH em 1956. A cidade de Hamburgo havia destinado determinados locais da mesma cidade a estacionamentos públicos sujeitos a pagamento e entregara à autora a guarda dos veículos em troca de determinada tarifa, sob condições previamente estabelecidas, 0 que foi amplamente levado ao conhecimento público. A ré, ao estacionar seu veículo num destes 
parques declarou expressamente aos agentes da autora, recusar a guarda do veículo e o pagamento da tarifa correspondente. Visando este pagamento, a autora propôs a ação e obteve ganho de causa, tendo o BGH baseado sua decisão no reconhecimento de existência de uma relação contratual fáctica fundada na utilizacão de fato do estacionamento.

Torna-se claro neste caso concreto que a fonte da relação jurídica não pode ser contratual, já que, de um lado, a manifestação de vontade que foi emitida, foi em sentido oposto a conclusão de negócio jurídico; e de outro, não se pode falar de negócio jurídico nascido de conduta concludente, pois a manifestação do agente foi em sentido contrário à conclusão a que normalmente leva sua conduta. De modo que, como pondera Larenz (52), o terreno da doutrina do negócio jurídico foi definitivamente abandonado, sendo preciso procurar a causa do nascimento da relação jurídica fora dela.

Se não se quiser aceitar as concepcões da doutrina das relacões contratuais fácticas, como o fez a decisão citada, tendo sido por isso muito criticada pela doutrina em geral, as duas soluções desenvolvidas no decurso do presente trabalho aparecem como perfeitamente possíveis. Tem-se então, de acordo com a concepção do ato existencial como ato-fato, que a relação de prestação e a obrigação de pagar a taxa relativa ao estacionamento se estabeleceu a partir do ato de utilização (suficiente), desprezando-se a manifestação de vontade porque esta, em se tratando de ato-fato, não tem a menor relevância.

A mesma conclusão se há de chegar segundo a concepcão do ato existencial como negócio jurídico fundado na proteção à confiança, pois nesta hipótese, defrontando-se os dois princípios: o da proteção à segurança visando a segurança do tráfico e o da autonomia da vontade fundamento do protesto, releva aquele sobre este. No tráfico em massa, onde, para o nascimento da relação jurídica não se requer senão o ato de utilização, ato típico, a protestatio facto contraria não vale. Hipótese semelhante foi julgada em 1925: uma indústria recebia energia elétrica da companhia municipal fornecedora; em dado momento, tendo sido aumentado o preço, recusou-se ao pagamento da taxa, alegando não reconhecer dito aumento por ser excessivo. Não obstante, continuou a utilizar e consumir energia elétrica. A objeção de que reiteradamente protestara por escrito contra a nova taxa, o tribunal respondeu que, tendo continuado a utilizar energia com o conhecimento de que só o podia sob as novas condicões, a elas se submeteu apesar do protesto, o qual «em verdade só tem o significado de uma protestatio facta con- traria, é incompatível com a conduta real do usuário e deve, por isso, ser afastada». Esta solução se impõe assim, em atendimento não do princípio da autonomia de vontade, mas da boa fé, não se precisando negar a existência de negócio jurídico como pretenderia a teoria das relações contratuais fácticas.

Nenhuma questão relativamente a ato existencial como tal foi suscitada em jurisprudência brasileira. Entretanto, são encontráveis decisões em que aparece uma fundamentação semelhante, no sentido da invocação da proteção à confiança e da boa fé relativamente ao tráfico negocial. Assim, por exemplo, na Revista dos Tribunais, vol. 145 , pg. 652 ; vol. 157, pg. 360 ; vol. 180 , pg. 663 ; vol. 246 , pg. 410 ; vol. 270 , pg. 277 ; vol. 314 , pg. 224

Todas estas decisões referem-se à hipótese de atraso no pagamento de prestacões em contratos de locação ou de compra e venda e foram decididas no sentido de que, o credor tendo aceitado anteriormente as prestações fora do prazo, tolerando portanto o atraso, é tido como tendo renunciado tacitamente à cláusula que estabelece o tempo para o pagamento, negando-se-lhe o direito de resolução por inadiplemento se este só se refere ao tempo do pagamento. O credor, por seu comportamento, fez com que nascesse no devedor, a convicção de que renunciara ao prazo ou que o prorrogara, «colocando em situação de não haver a ação de resolução ex abrupto» (RT, vol. 270, pg. 277). A boa fé exige que esta confiança depositada pelo devedor no significado da conduta do credor não fique desprotegida, vindo a prejudicá-lo.

1 - Infelizmente não me foi possível dispor desta obra.

2 - Pontes de Miranda. Tratado de Direito Privado. Rio de Janeiro, Ed. Borsoi, 1972, V. 38, p. 30.

3 - Nikisch. Archiv für die Civilistische Praxis, 1958, V. 157, fasc. 1, p. 106

4 - Esser, Josef. Gedanken zur Dogmatik der "faktischen Schuldverhältnisse". Archiv für die Civilistische, V.

$5-6-7-$ Burdau, Georges. Problèmes Politiques Fondamentaux de l'Etat. Paris, Université de Paris, Institut d'Etudes Politiques, fasc. 3, p. 246, 260, 261.

8 - Siebert, Wolfgang. Faktische Vertragsverhältnisse. Karlsruhe, C. F. Müller, p. 12. (Conferência realizada em Karlsruhe em 21.06.1957).

9 - Pontes de Miranda. Tratado. V. 38, p. 38.

10 - obra citada, V. 38, p. 39 
11 - Utilizo a expressão "manifestação de vontade" em sentido amplo, compreendendo também as atuações volitivas ou manifestações simples.

12 - Utilizo no decorrer do trabalho indiferentemente as expressões |"negócio jurídico bilateral" ou "contrato".

13 - Pontes de Miranda. Tratado. V. 38, p. 30

14 - obras citada, V. 38, p. 30

15 - obra citada, V. 38, p. 30

16 - obra citada, V. 38, p. 41

17 - obra citada, V. 38, p. 45

18 - Larenz, Karl. Lehrbuch des Schuldrechts. München, C. H. Beck'sche Verlagsbuchhandlung, 1962, V. 1, p. 89

19 - Haupt. Uber Faktische Vertragsverhältnisse. Apud Siebert, Faktische Vertragsverhältnisse, p. 17.

20 - Pontes de Miranda. Tratado. V. 38, p. 31

21 - Flume, Werner, Archiv für die Civilistische Praxis, V. 157

22 - Pontes de Miranda. Tratado. V. 38, p. 31

23 - Larenz, Karl. Lehrbuch. V. 1, p. 33

24 - Couto e Silva, Clóvis. A obrigação como processo. Porto Alegre, Emma, 1964, p. 95.

25 - Pontes de Miranda. Tratado. V. 3, p. 7

$26-$ - obra citada, V. 4 , p. 217

27 - obra citada V. 1, p. 91

28 - Ballerstedt, Kurt, Archiv für die Civilistische Praxis, V. 157, fasc. 1, p. 105

29 - Siebert, Wolfgang. Faktische Vertragsverhältnisse. P. 29

30 - obra citada, p. 26

31 - Apud Siebert, obra citada, p. 29

32 - Staudinger. Kommentar. Berlin, Schweizer Verlag, 1957, V. 1, p. 496

33 - - obra citada, p. 532

34 - - obra citada, p. 586

35 - obra citada, p. 586

36 - Flume, Werner Das Rechtsgeschuift und das rechtlich relevante Cerhalten. Archiv für die Civilistische Praxis, V. 161 , fasc. 1 , p. 61

37 - Staudinger. Kommentar. V. 1, p. 585

38 - Siebert, Wolfgang. Faktische Vertragsverhältnisse. p. 32

$39-$, obra citada, p. 32

40 - obra citada, p. 36

41 - Esser, Josef. Gedanken zur Dogmatik der "faktischen Schuldverhältnisse". Archiv für die Civilistische Praxis, V. 157 , fasc. 1 , p. 97
42 fasc. 1, p. 105

43 - Pontes de Miranda. Tratado.. V. 38, p. 29 e seguintes

44 - Larenz, Karl. Lehrbuch. V. 1, p. 33 e seguintes Mais recentemente, na Parte Geral do seu Direito Civil, 1967, p. 515 e seguintes, Larenz reformulou em parte sua opinião, inserindo no ato de quem se utiliza de uma prestação existencial, uma "vontade latente" de deixar valer seu ato "como" aceitação da oferta pública. Ora, perguta-se: que significado e importância jurídica pode ter uma "vontade latente de aceitar"- O que Larenz com isto pretende é não excluir totalmente os atos existenciais do âmbito da teoria geral do contrato, permitindo que sejam enquadrados na disposição do $\S 151$ do BGB (arts. 1079 e 1084 do Código Civil Brasileiro).

$45-1$, obra citada, p. 35

46 - Pontes de Miranda. Tratado. V. 2, p. 373

47 - Larenz, Karl. Lehrbuch, p. 35: Archiv für die Civilistische Praxis, V. 157, fasc. 1, p. 117 e seguintes

48 - Bidlinsky, Franz. Privatautonomie und objektive Grundlagen des Verpflichtenden Rechtsgeschäftes. Wien, Springer Verlag, 1967, p. 91

49 - Raiser, Ludwig. Die Zukunft des Privatrechts. Berlin. Sociedade Jurídica de Berlim. Conferência realizada em 1971

50 - Schmidt-Rimpler, Walter. Grundfragen einer Erneuerung des Vertragsrechts. Archiv für die Civilistische Praxis, V. 27 da nova série, p. 130 e seguintes.

51 - Siebert, Wolfgang. Faktische Vertragsverhältnisse. P. 38

52 - Larenz, Karl. Lehrbuch. P. 34 